\title{
CHILDREN'S AGENCY IN THE OUEST FOR FOOD SOVEREIGNTY; THE CASE OF SAN JERÓNIMO AMANALCO
}

\section{AGENCIA DE LA NIÑEZ EN LA BÚSOUEDA DE SOBERANÍA ALIMENTARIA, EL CASO DE SAN JERÓNIMO AMANALCO}

\author{
María del Rosario González Macías*', Cristóbal Santos Cervantes²
}

\begin{abstract}
Qhildren are vulnerable to food problems, but they have less choice, participation and information than adults in such matters. Social Science discussions that approach the understanding and social inclusion of children are minimal, and there are limited social spaces and tools provided to them to participate in various alternatives to problems such as control of the food industry and the disconnection between production and consumption. The action research was carried out under an ethnographic approach, with the participation of 23 children from San Jerónimo Amanalco, Texcoco, State of Mexico. The objective was to understand the children's agency with respect to their food experiences, knowledge and practices in a rural-urban space, through the exchange of knowledge and constructive-productive actions. There are physical conditions, knowledge and attitude in children to collaborate in food sovereignty processes, but it is necessary to give them conducive social conditions. Their agency supports the transmission of the peasant culture that persists in their grandparents and can be renewed by this new generation that maintains ties with the land. Children are able to recognize natural wealth as the basis of the productive phase for a healthy diet, and this productive process means a bond of identity with their predecessors, their physical environment and their community.
\end{abstract}

KEYWORDS: Child protagonism, food culture, domination, rurban space, production.

'Universidad Autónoma Chapingo. Maestría en Desarrollo Rural Regional, km 38.5 Carretera México-Texcoco. C. P. 56230. Chapingo, Texcoco, Estado de México.

${ }^{2}$ Universidad Autónoma Chapingo, Centros Regionales, km 38.5 Carretera México-Texcoco. C. P. 56230. Chapingo, Texcoco, Estado de México*Corresponding author: roussgoma2@gmail.com Teléfono: 4591081409

Received: August 28, 2019 Accepted: April 18, 2020

Please cite this article as follows (APA 6): González Macías, M. R., \& Santos Cervantes C. (2020). Children's agency in the quest for food sovereignty; the case of San Jerónimo Amanalco.Textual, 75, 271-294. doi: 10.5154.r.textual.2020.75.13 


\section{RESUMEN}

a niñez es vulnerable ante las problemáticas alimenticias, sin embargo, tiene menor posibilidad de decisión, participación e información que los adultos. Son mínimas las discusiones de Ciencias Sociales que acercan a la comprensión e inclusión social de la niñez y son limitados los espacios sociales y herramientas brindadas para que participe en diversas alternativas ante problemáticas como el control la industria alimentaria y la desvinculación entre producción y consumo. La investigación-acción se realizó con un enfoque etnográfico, participaron 23 niños y niñas de San Jerónimo Amanalco, Texcoco, Estado de México. El objetivo fue comprender la agencia de la niñez con respecto a sus experiencias, conocimientos y prácticas alimentarias en un espacio rural-urbano, por medio del intercambio de saberes y acciones constructivo-productivas. Existen las condiciones físicas, los conocimientos y la actitud en niños y niñas, para colaborar en procesos de soberanía alimentaria, falta darles las condiciones sociales. Su agencia apoya a la transmisión de la cultura campesina que persiste en los abuelos y puede renovarse mediante esta nueva generación que mantiene lazos con la tierra. En la niñez hay un reconocimiento de la riqueza natural como base de la fase productiva de una alimentación sana, y este proceso productivo es un vínculo identitario con sus antecesores, su entorno físico y su comunidad.

PALABRAS CLAVE: Protagonismo infantil, cultura alimentaria, dominación, espacio rururbano, producción.

\section{INTRODUCTION}

Mexican children are vulnerable to problems such as low food access and malnutrition. They are influenced by the power of adults and the subjective control of consumer advertising, and they have little possibility of making decisions and getting information; however, they have knowledge, experience and potential as social agents in the quest for better food conditions in their immediate environment.

Children's food experiences, potentialities and knowledge have not been explored and promoted by qualitative research, which

\section{INTRODUCCIÓN}

Niños y niñas en México son vulnerables ante problemáticas como el bajo acceso alimenticio y la malnutrición, se ven influenciados por el poder de los adultos y el control subjetivo de la propaganda de consumo, tienen baja posibilidad de decisión e información, sin embargo, poseen conocimientos, experiencias y potencialidades como agentes sociales para la búsqueda de mejores condiciones alimenticias en su entorno inmediato.

Las experiencias, potencialidades y conocimientos alimentarios de niños y niñas 
would provide a basis for recognizing and including them as protagonists. There is an abundance of research on the diet of children under five as objects of intervention (Pelcastre, et al., 2006), focused on the participation of their parents. Research on children over five is scarce and focused on the school environment, and is also quantitative, experimental and interventionist (Quizán, et al., 2013); however, there is a theoretical gap in the critical perspective of children as agents of food transformation.

Access to the basic right to food represents an unsolved problem in Mexico, as $23.4 \%$ of the population lacks access to food (CONEVAL, 2014). There are 21 million children living in conditions of poverty and four million 700 thousand in extreme poverty, which directly influences their diet. In the five- to fourteen-year-old age group, chronic malnutrition affects $7.25 \%$ of urban populations, and the figure doubles in rural ones (Unicef, 2016); likewise, childhood obesity is a priority public health problem (Instituto Mexicano del Seguro Social, 2014). Peasant food production is becoming disconnected from the new generations, the producers are mainly older people and the culture of food sovereignty in rurban spaces is permeated by the dynamics and strategies of daily life intertwined with the cities.

Eating as a process-system implies interdependence with the sociocultural system (Aguilar, 2014, p.12), interrelation of consumption, production and socio-economic structure as factors that are imposed on the daily food practices of the actors (Nájera \& Álvarez, 2010), in contemporary so- no han sido explorados y potenciados desde la investigación cualitativa, lo cual proporcionaría una base para reconocerlos e incluirlos como agentes protagónicos. Abundan investigaciones interesadas en la alimentación en menores de cinco años como objetos de intervención (Pelcastre, et al., 2006), enfocadas en la participación de sus padres. Las investigaciones con mayores de cinco años son escasas y se enfocan en el ámbito escolar, además, son de tipo cuantitativo, experimental y de intervención (Quizán, et al., 2013); no obstante, existe un vacío teórico en la perspectiva crítica de la niñez como agente de transformación alimentaria.

El acceso al derecho básico de alimentación representa un problema no resuelto en México, $23.4 \%$ de la población tiene carencia por acceso a la alimentación (CONEVAL, 2014). Hay 21 millones de niños en condiciones de pobreza y cuatro millones 700 mil en pobreza extrema, lo cual influye directamente en su alimentación. En el grupo de edad de cinco a catorce años la desnutrición crónica es de 7.25 \% en las poblaciones urbanas, y la cifra se duplica en las rurales (Unicef, 2016), asimismo, la obesidad infantil es un problema prioritario de salud pública (Instituto Mexicano del Seguro Social, 2014). La producción campesina de alimentos está desligándose de las nuevas generaciones, los productores son principalmente personas mayores y la cultura de soberanía alimentaria en los espacios rururbanos se ve permeada por las dinámicas y estrategias de la vida cotidiana entrelazadas con las ciudades.

La alimentación como proceso-sistema implica interdependencia con el sistema 
ciety that encompasses broad phenomena such as the domination of the market for processed, industrialized and mass-produced food that displaces local production (Ayora, 2017), especially in rurban areas.

This study was carried out in a rurban context, which, according to Sobrino (2003, p.105), is characterized by, among other aspects, occupational diversification, permanence of land tenure, displacement of agricultural activities as the fundamental support for family sustenance, demand for public services and urban expansion in rural areas. Urbanization brings with it new patterns of social, economic, professional, cultural and food behavior, a pressure of urban uses on agricultural land uses (Cardoso, 2012) and with this the possibilities of local production are limited.

\section{UNIVERSE AND PURPOSE OF THE STUDY}

The relationship between Mexico City and the peripheral municipalities, mainly those that retain rural features, implies transformations in eating patterns due to the influence of global marketing, diversification of income sources and the introduction of junk food products.

San Jerónimo Amanalco, Texcoco, Mexico, retains rural characteristics and agricultural production and forms part of the periphery being gradually absorbed by the city, in such a way that production and consumption strategies are redefined and modified to the detriment of local practices. New generations are shaped in an environment that undervalues healthy, local and traditional foods, including the food sociocultural (Aguilar, 2014, p.12), interrelación del consumo, la producción y la estructura socioeconómica como factores que se imponen a las prácticas alimentarias cotidianas de los actores (Nájera \& Álvarez, 2010), en la sociedad contemporánea que comprende fenómenos amplios como la dominación del mercado de alimentos procesados, industrializados y masificados que desplazan a la producción local (Ayora, 2017), sobre todo en las áreas rururbanas.

Este estudio se llevó a cabo en un contexto rururbano, que de acuerdo con Sobrino (2003, p.105), se caracteriza, entre otros aspectos, por diversificación ocupacional, permanencia de la tenencia de la tierra, desplazamiento de las actividades agropecuarias como el soporte fundamental del sustento familiar, demanda de servicios públicos y expansión urbana en suelo rural. La urbanización conlleva nuevas pautas de comportamiento social, económico, profesional, cultural y alimenticio, una presión de los usos urbanos sobre los usos de suelo agrícola (Cardoso, 2012) y con ello se limitan las posibilidades de producción local.

\section{UNIVERSO Y PROPÓSITO DEL ESTUDIO}

La relación entre la Ciudad de México y los municipios periféricos, principalmente aquellos que conservan rasgos rurales, implica transformaciones en los patrones alimenticios por el influjo de la mercadotecnia global, la diversificación de las fuentes de ingreso y la introducción de productos chatarra.

San Jerónimo Amanalco, Texcoco, México, conserva características rurales y pro- 
system that implies their existence. The eating patterns in which children are immersed are due to a series of social and cultural factors within populations where food security and sovereignty are increasingly blurred.

Food sovereignty has been conceptualized as an alternative to food neoliberalism, based on a model of peasant agriculture (Ramírez, 2017, p. 95) from within communities, with the strengthening of their own life strategies, which considers the available resources and their cultural tendencies. From this perspective, eating as a unit is of interest, both as a biological act and as a socio-cultural process-system, which integrates production with consumption and includes the peasants.

Based on the concern to make children visible, to recognize their social and cognitive potentialities, their willingness to initiate processes of food transformation and to identify their interest in plants and animals, the collective work was consolidated in correspondence with the situation of disarticulation between production and consumption occurring in San Jerónimo Amanalco.

Food problems are interrelated with others that are structural and systemic and cannot be solved from a single front. Simultaneous governmental, structural and cultural actions are needed; however, targeted and local changes can be made with an expansive and long-term vision. From this perspective, What can be the role of children in recognizing the local food culture for the improvement of their ducción agropecuaria y forma parte de la periferia absorbida gradualmente por la urbe, de tal forma que las estrategias de producción y consumo van redefiniéndose y modificándose en detrimento de las prácticas locales. Las nuevas generaciones se configuran en un ambiente de subvaloración de los alimentos sanos, locales y tradicionales, con todo y el sistema alimentario que implica su existencia. Los patrones de alimentación en los que están inmersos niños y niñas obedecen a una serie de factores sociales y culturales al interior de las poblaciones donde se desdibuja cada vez más la seguridad y soberanía alimentaria.

La soberanía alimentaria se ha conceptualizado como alternativa al neoliberalismo alimentario, basada en un modelo de agricultura campesina (Ramírez, 2017, p. 95) desde adentro de las comunidades, con el fortalecimiento de sus propias estrategias de vida, que considera los recursos disponibles y sus tendencias culturales. Desde esta perspectiva, interesa la alimentación como unidad, tanto acto biológico como proceso-sistema sociocultural, que integra a la producción con el consumo e incluye a los campesinos.

A partir de la inquietud por visibilizar a niños y niñas, por reconocer sus potencialidades sociales y cognitivas, su disposición de iniciar procesos de transformaciones alimenticias e identificar su interés por las plantas y los animales, se consolidó el trabajo colectivo en correspondencia con la situación de desarticulación entre la producción y el consumo que se presenta en San Jerónimo Amanalco. 
diet based on what they know and have? Which of their experiences and knowledge translated into food production habits can be strengthened with and from children?

The aim of the study was to identify in San Jerónimo Amanalco the knowledge, experiences and productive practices of children between six and eight years of age, through the exchange of knowledge, as well as productive-configurative actions focused on recognizing and strengthening their agency and food practices that enable their reflection and participation in the productive environment and contribute to strengthening community processes in food.

\section{METHODOLOGY}

The action research was carried out in San Jerónimo Amanalco, under an ethnographic approach from October 2016 to July 2018. Twenty-three children aged 6 to 8 , parents and teachers participated. A structured interview was conducted with 20 children, and five ludic workshops were held for children to express themselves through drawings and games or through opinions based on key questions. Configurative-productive workshops were held periodically for establishing a school garden and one in their backyards.

Convenience sampling was used in the study, with participants who ranged in age from six to eleven years old and whose focus, due to their age, is on three pillars of operability: action, play and work; this age range is characterized by openness to the external world and by the accelerated acquisition of skills for interaction (Mansilla,
Los problemas alimentarios están interrelacionados con otros que son estructurales y sistémicos y no se solucionan desde un solo frente, son necesarias acciones gubernamentales, estructurales y culturales simultáneas, sin embargo, se pueden hacer cambios focalizados y locales con una visión expansiva y a largo plazo. Desde esta perspectiva ¿Cuál puede ser el rol de la niñez en el reconocimiento de la cultura alimenticia local para el mejoramiento de su alimentación a partir de lo que saben y disponen? ¿Cuáles de sus experiencias y conocimientos traducidos en hábitos de producción alimentaria pueden fortalecerse con y desde los niños y niñas?

El propósito del estudio fue identificar en San Jerónimo Amanalco los conocimientos, experiencias y prácticas productivas de la niñez, de entre seis y ocho años de edad, por medio del intercambio de saberes, así como acciones productivo-configurativas enfocadas a reconocer y fortalecer su agencia y las prácticas alimentarias que posibiliten su reflexión y participación en el ámbito productivo y contribuyan a potenciar procesos comunitarios en alimentación.

\section{METOdOLOGÍA}

La investigación-acción se realizó en San Jerónimo Amanalco, con un enfoque etnográfico desde octubre de 2016 hasta julio 2018, participaron 23 niños y niñas de 6 a 8 años de edad, padres de familia y profesores. Se realizó una entrevista estructurada a 20 niños y niñas, cinco talleres lúdicos, de expresión mediante dibujos y juegos o a partir de la opinión a partir de preguntas clave; se efectuaron periódicamente 
2000). At this stage, cognitive abilities such as memory and language skills increase, logical and concrete thinking is consolidated, self-concept becomes more complex and there is a co-regulation between parents and children, which is reflected in the control that gradually passes from parents to children (Papalia, Wendkos \& Duskin, 2004). According to psychosocial, cognitive and physical development, which can vary according to context and culture, the age of six to eight years is ideal for forming critical, conscious subjects open to collective participation.

The analysis initiated with constant reflection and co-interpretation regarding the habits, patterns, feelings, knowledge and actions of the children and the impact of various actors, contexts and factors on their eating practices. The workshops were of a reflective and critical nature, with the dual purpose of finding out opinions and creating awareness.

A documentary review, participant observation, photo-taking, recordings and a field log were used for the collection of information. The delegates, the person in charge of the primary sector, Health Center representatives, district attorneys and community residents were key agents for information gathering.

The critical perspective applied was the Sociology of Childhood, which accounts for the adult-centric power and macrosocial control in which children are immersed, and which exposes their condition as social agents, capable of making changes in the ways of thinking and doing in their talleres configurativo-productivos para la instalación de un huerto escolar y en sus traspatios.

La muestra fue por conveniencia, con participantes en el inicio de la segunda infancia, que va de los seis a los once años y se centra en tres pilares de la operatividad: acción, juego y trabajo; la cual se caracteriza por su apertura al mundo externo y por la acelerada adquisición de habilidades para la interacción (Mansilla, 2000), en esta etapa aumentan las capacidades cognitivas, como la memoria y las habilidades lingüísticas, se consolida el pensamiento lógico y concreto, el autoconcepto se vuelve más complejo y hay una corregulación entre padres e hijos, que se refleja en el control que pasa gradualmente de los padres a los niños (Papalia, Wendkos \& Duskin, 2004). De acuerdo con el desarrollo psicosocial, cognitivo y físico, que puede variar de acuerdo con el contexto y la cultura, la edad de seis a ocho años es ideal para formarse como sujetos críticos, conscientes y con apertura a participar colectivamente.

El análisis partió de la constante reflexión y co-interpretación respecto a los hábitos, patrones, sentires, saberes y acciones de la niñez y la incidencia de diversos actores, contextos y factores en torno a sus prácticas de alimentación. Los talleres fueron de carácter reflexivo y crítico, con el doble propósito de conocer las opiniones y crear consciencia.

Se hizo revisión documental, observación participante, toma de fotografías, grabaciones y bitácora de campo para la recolección de información. Los delegados, el 
immediate environment. The postulates of the Sociology of Childhood (Rodríguez, 2007, p.10) were taken up again, so the children were subjects of study per se and constituted the units of observation, which allowed them to speak with their own voice about their experiences, from a present dimension and not only as future adults. Childhood was viewed as part of a given social structure and from an intergenerational perspective.

Ethnography was essential for the approach and dialogue with the children (Pia, 2004; Gaitán, 2006; Quecha, 2014), co-interpretation (Dietz \& Álvarez, 2014) and collaboration (Reygadas, 2014). Therefore, action research was not a linear process with predestined decisions; it was built and adapted to specific opinions and circumstances to do collaborative and dialogical research with them and to visualize food as a systemic and procedural entity within a specific context that accounts for its dynamic configuration.

The ethnographic approach allowed us to visualize agency, which alludes to the capacity for action of individuals, made possible and limited at the same time by social relations, institutions and structures of society. In this sense, agency is understood as a contextually situated relational capacity, not a universal ontological quality, but rather a historically variable emergent capacity, conditioned structurally, institutionally and intersubjectively, which depends on the asymmetrical configuration of power relations and structural inequalities (Yopo, 2016). encargado del sector primario, representantes del Centro de Salud, fiscales y habitantes de la comunidad fueron agentes clave para la recolección de información.

La perspectiva crítica que se retomó fue la Sociología de la Infancia que da cuenta del poder adultocéntrico y el control macrosocial en que están inmersos niños y niñas, y que expone su condición de agentes sociales, capaces de hacer cambios en las maneras de pensar y de hacer en un entorno inmediato. Fueron retomados los postulados de Sociología de la Infancia (Rodríguez, 2007, p.10), así, los niños fueron sujetos de estudio per se y constituyeron las unidades de observación, lo que les permitió hablar con voz propia de sus experiencias, desde una dimensión presente y no solo como futuros adultos. Se contempló a la infancia como parte de una estructura social dada y desde una perspectiva intergeneracional.

La etnografía fue esencial para el acercamiento y diálogo con la niñez (Pia, 2004; Gaitán, 2006; Quecha, 2014), la co-interpretación (Dietz \& Álvarez, 2014) y la colaboración (Reygadas, 2014), por tanto, la investigación-acción no fue un proceso lineal con decisiones predestinadas, se fue construyendo y adaptando a las opiniones y circunstancias específicas, para hacer investigación dialógica y colaborativa con ellos y, visualizar a la alimentación como una entidad sistémica y procesual dentro de un contexto específico que da cuenta de su configuración dinámica.

El enfoque etnográfico, permitió visualizar la agencia, que alude a la capacidad 
The ethnography around food practices accounts for sociocultural processes and dynamics (Glockner, 2007, p. 65). In this study, it allowed us to approach the food process as "a historical process nurtured by forces, struggles and conflicts between the various systems that interrelate with it" (Blanco, 2016, p. 137), which has to do with the development of capitalism and the consumer society, as well as the promotion of consumption and immediate access to it, as part of the cogs of the historicity of the system and the feeding process (Bertrán, 2010, p. 387).

From this perspective, food is conceived as a systematic and processual entity, as a historical and cross-cultural phenomenon not only because of the need to guarantee life, but also because of the forms that this need acquires in different times and spaces (Aguilar, 2001, p. 15). The anthropology of food accounts for the dynamic configuration of the food system and can be interpreted with its specific historical and geographical characteristics (Aguilar, 2001, p.11) and gives the possibility of including children as social agents with the opportunity to actively participate in food transformations (Zanabria, Fragoso \& Martínez, 2007).

\section{DISCUSSION OF RESULTS}

Peasant production in San Jerónimo, despite its weakening process, offers options for family food and nutrition. The children possess knowledge of peasant production and have possibilities and protagonism different from those living in rural areas or in the city itself, since the global transforma- de acción de los individuos, posibilitada y limitada a la vez por las relaciones sociales, las instituciones y estructuras de la sociedad. En este sentido, la agencia es entendida como una capacidad relacional contextualmente situada, no es una cualidad ontológica universal, más bien es una capacidad emergente históricamente variable, condicionada estructural, institucional e intersubjetivamente, que depende de la configuración asimétrica de las relaciones de poder y las desigualdades estructurales (Yopo, 2016).

La etnografía en torno a las prácticas alimentarias, da cuenta de los procesos y dinámicas socioculturales (Glockner, 2007, p. 65), en este estudio permitió abordar al proceso alimentario como "un proceso histórico nutrido de fuerzas, luchas y conflictos entre los diversos sistemas que interrelacionan con él" (Blanco, 2016, p. 137), que tiene que ver con el desarrollo del capitalismo y la sociedad de consumo, la promoción al consumo, y el acceso inmediato a él, como parte de los engranajes de la historicidad del sistema y del proceso de alimentación (Bertrán,2010, p. 387).

Desde esta perspectiva, la alimentación se concibe como una entidad sistemática y procesual, como un fenómeno histórico y transcultural no solo por la necesidad de garantizar la vida, sino por las formas que en diferentes tiempos y espacios va adquiriendo esta necesidad (Aguilar, 2001, p. 15). La antropología de la alimentación da cuenta de la configuración dinámica del sistema de alimentación y puede ser interpretado con sus especificidades históricas y geográficas concretas (Aguilar, 
tions affecting social and individual structures influence them in different ways. These new generations are vulnerable and are under the decision-making power and opinion of adults (Gaitán, 2006), and under the control of the social structure through TV advertising (Bustelo, 2012).

\section{FOOD EXPERIENCES, KNOWLEDGE AND PRACTICES}

Children with a rural-urban relationship as complex as that of San Jerónimo have a vast knowledge of food production. All those children whose families have backyard animals participate in the latter's care, 18 of the 20 interviewed have backyard or milpa production, and 12 of those 18 participate in production in support of the father who has the greatest responsibility in agricultural production (Figure 1).

Boys and girls have gender-specific tasks, since while boys carry out activities such as carrying, using agricultural implements and planting, girls focus on caring for animals and backyard crops.

Figure 1. Childe's partisipaton in agricultura. Figura 1. Participación de la niñez en la agricultura

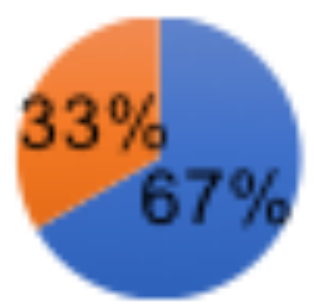

Participates Does not participates
2001, p.11) y da la posibilidad de incluir a los niños como agentes sociales con oportunidad de participar activamente en las transformaciones alimentarias (Zanabria, Fragoso \& Martínez, 2007).

\section{DISCUSIÓN DE RESULTADOS}

La producción campesina en San Jerónimo, pese a su proceso de debilitamiento, ofrece opciones para la alimentación y nutrición de las familias. Los niños y niñas poseen conocimientos de producción campesina, tienen posibilidades y protagonismo diferentes a quienes viven en zonas rurales o propiamente en la ciudad, ya que las transformaciones globales que afectan a las estructuras sociales e individuales los influyen de diferente manera. Estas nuevas generaciones son vulneradas y están bajo el poder de decisión y opinión de los adultos (Gaitán, 2006), y bajo el control de la estructura social mediante los anuncios televisivos (Bustelo, 2012).

\section{EXPERIENCIAS, CONOCIMIENTOSY PRÁCTICAS ALIMENTARIAS}

Los niños y niñas con una relación rural-urbana tan compleja como la de San Jerónimo, tienen un vasto conocimiento de la fase productiva de la alimentación. Todos aquellos niños y niñas en cuyas casas hay animales de traspatio, participan en su cuidado, 18 de los 20 que se les aplicó una entrevista tienen producción de traspatio o milpa, y 12 de esos 18 participan en la producción como apoyo al padre que es quien tienen una mayor responsabilidad en la producción agrícola (Figura 1). 
Consumption is becoming disconnected from traditional production; however, children have interest, knowledge and skills, so they were included as protagonists in productive-configurative activities aimed at food sovereignty.

From the valuation of peasant agriculture in the new generations, as a means to complement the usual diet, it is feasible to strengthen a culture of food sovereignty in a space that is gradually being absorbed by urbanization as is San Jerónimo. The knowledge, experience, skills and interest in knowing of children between six and eight years of age are sufficient to be active and recognized agents in decision-making.

Of the knowledge that children possess, the importance given to their natural wealth, mainly water and the bush as providers of food in the community, stands out; these two elements are determining factors for the existence of production and the persistence of this knowledge. Their knowledge of the productive phase is very rich; in answering the question What do they produce in the town that contributes food to families?, they showed a deep knowledge about the variety of foods from the community (Table 1); their drawings showed a greater variety of foods than that elicited in the workshop for parents when asked the same question.

These children identify the river, fish, fruit, the bush, pigs and sheep as sources of food, and even recognize wild mushrooms and plants from the bush. The physical space and natural wealth of the people are playing an important role in shaping
Las tareas específicas por género entre niños y niñas están diferenciadas, mientras que los niños llevan a cabo actividades de acarreo, uso de implementos agrícolas y siembra, las niñas se enfocan en el cuidado de los animales y cultivos de traspatio.

El consumo está desvinculándose de la producción tradicional, sin embargo, niños y niñas tienen interés, conocimientos y habilidades, por lo cual, se incluyeron como protagonistas en actividades productivo-configurativas encaminadas a la soberanía alimentaria.

Desde la valoración de la agricultura campesina en las nuevas generaciones, como medio para complementar la dieta habitual, es factible fortalecer una cultura de soberanía alimentaria en un espacio que se absorbe poco a poco por la urbanización como es San Jerónimo. Los conocimientos, experiencias, habilidades e interés por conocer de niños y niñas de seis a ocho años de edad son suficientes para ser agentes activos y reconocidos en la toma de decisiones.

Entre los conocimientos que posee la niñez, se destaca la importancia otorgada a su riqueza natural, principalmente el agua y el monte como proveedores de alimentos en el pueblo; estos dos elementos son determinantes para la existencia de la producción y la persistencia de esos conocimientos. Sus saberes de la fase productiva son muy ricos, al responder la pregunta generadora ¿Qué producen en el pueblo que aporte alimentos a las familias?, manifestaron un conocimiento profundo sobre la variedad de alimentos provenientes 
Table 1. Children's knowledge of food diversity in San Jerónimo

Cuadro 1. Conocimiento en la niñez de la diversidad alimenticia existente en San Jerónimo

\begin{tabular}{ll}
\hline \multicolumn{1}{c}{ Type/Tipo } & \multicolumn{1}{c}{ Species/Especies } \\
\hline Agricultural/Agrícola & $\begin{array}{l}\text { Orange, pear, apple, lime, plum, coriander, capulin, pumpkin, lemon, peach, corn, nopales, } \\
\text { apricot, pears, tejocotes, peas and beans./ } \\
\text { Naranja, pera, manzana, lima, ciruela, cilantro, capulín, calabaza, limón, durazno, maíz, nopa- } \\
\\
\text { les, chabacano, peras, tejocotes, chicharos y habas. }\end{array}$ \\
Livestock/Pecuaria & Chickens, cows, pigs and sheep./Gallinas, vacas, cochinos y borregos. \\
Collection/Recolección & Mushrooms and wild plants from the bush./Hongosy plantas silvestres provenientes del monte.
\end{tabular}

Source: Author-made based on field and workshop information.

Fuente: Elaboración propia con base en la información de campo y taller.

their knowledge of food. Water for them is an important factor in "growing the milpa" and in "having fruit and watering it," while the bush is the place where the milpa is and they go there with their parents or grandparents to help them plant or collect natural area soil, mushrooms and herbs.

Their perception of access to food includes purchasing and their own production; however, their consumption is more related to purchasing. With regard to the question How can we get healthy food?, they suggested "planting," "planting tomatoes," "planting corn," "making a garden," "with fruit trees."

The importance of production volume is less than its symbolic and historical value present in the subjectivity of the children, that knowledge rooted in their predecessors, mainly in their grandparents, many of whom are still engaged in the self-consumption milpa; although it is not their main economic activity, it has influence on their grandchildren.

These children have a deep knowledge of their environment and how it contrib- de la misma comunidad (Cuadro 1), sus dibujos demostraron una mayor variedad a la arrojada en el taller para padres con la misma pregunta.

Esa niñez identifica al río, los peces, las frutas, el monte, los cochinos y borregos como fuentes de comida, reconoce incluso a los hongos y plantas silvestres provenientes del monte. El espacio físico y la riqueza natural del pueblo están jugando un papel importante en la conformación de su conocimiento sobre la alimentación, el agua para ellos es un factor importante para que "crezca la milpa", para "tener frutas y regarlas", el monte es el lugar donde está la milpa y ellos van con sus padres o abuelos para ayudarles a sembrar o recoger tierra de monte, hongos y yerbas.

Su percepción respecto al acceso a los alimentos incluye la compra y la producción propia, sin embargo, su consumo se relaciona más con la compra. Con respecto a la pregunta ¿Cómo podríamos hacer para obtener alimentos saludables? Sugirieron que "sembrando", "plantar jitoma- 
utes to their diet. There is a close relationship between the natural wealth identified by these children, local production and how they imagine it would provide a good diet. The same concepts and foods that they perceived as healthy foods coincide for the most part with those they identified as being produced in their community.

The recognition, dynamization and use of peasant production would open up the possibility of contributing to good nutrition in the future of the community. Food production in San Jerónimo is a complementary activity, mainly carried out by the grandparents who preserve the culture of peasant production as a deep-rooted way of life; it is practiced and has symbolic importance for older people (Ochoa, 2013), who despite having other economic activities keep their milpa. Until 1970 most of the community's income came from working in the fields, as almost 100 $\%$ of the economically active population was engaged in the cultivation of corn, barley, broad beans, wheat, potatoes and alfalfa, for consumption and sale; domestic animal husbandry and vegetable and fruit production were complementary (Pérez, 2008).

In recent decades, the milpa has diminished in economic importance and as a means of family support; young families have activities from other labor sectors as their main source of income, but they acquired and possess productive knowledge. The transmission of this knowledge has reached the new generations, but it has been little explored and potentialized. tes", "plantar maíz”, "hacer un huerto”, “con árboles de frutas".

La importancia del volumen de producción es menor que su valor simbólico e histórico presente en la subjetividad de la niñez, ese saber arraigado en sus antecesores, principalmente en sus abuelos, que muchos se dedican todavía a la milpa de autoconsumo, aunque no sea su principal actividad económica, tiene influencia en sus nietos.

Esa niñez tiene profundo conocimiento de su medio y de cómo aporta este a su alimentación. Existe una estrecha relación entre la riqueza natural que identifica a su pueblo, la producción local y cómo ellos se imaginan que sería una buena alimentación. Los mismos conceptos y alimentos que percibieron ellos como alimentos saludables, coinciden en su mayoría con aquellos que identificaron que se producen en su comunidad.

El reconocimiento, dinamización y uso de la producción campesina abriría la posibilidad de contribuir a la buena alimentación en el futuro de la comunidad. La producción de alimentos en San Jerónimo es una actividad complementaria, a la que se dedican principalmente los abuelos, quienes conservan la cultura de producción campesina como una forma de vida arraigada, es practicada y tiene importancia simbólica para las personas mayores (Ochoa, 2013), quienes pese a tener otras actividades económicas conservan su milpa. Hasta 1970 la mayor parte de los ingresos provenían del trabajo en el campo, casi el $100 \%$ de la población económicamente 
This productive knowledge present in children, together with being a factor in developing bonding identity, is a fundamental and potential element for a peasant regeneration process as an alternative to better feed themselves and as a seed for the inclusion of children in the productive process. It is an important factor, especially in areas where the diet of the new generations is based mainly on products that come from outside, where the children's diet has little fruit and vegetables and their daily intake includes sweets and junk food products.

Currently, there are no direct actions with children, neither community nor governmental, to regulate the consumption of junk food products. There are no spaces dedicated to children to reflect on their diet, and they are not integrated as social agents, neither from the participation that is a right, nor from the information provided so that they assume a healthy diet.

Although there are international decrees at the national level in favor of children's rights, just as in San Jerónimo, at the national level there is the challenge of opening up these participation spaces to children, where they can give their opinions and be heard, in order to build in collaboration with them their present and future. Within this framework, it is essential to promote the structural, local and cultural conditions to make these rights effective. The aim of this work was not to portray this generation as victims, but rather to show alternatives from the standpoint of protagonism and to recognize them as agents of change, who have their own perceptions of the world and knowledge to activa se dedicaba al cultivo de maíz, cebada, haba, trigo, papa y alfalfa, para consumo y venta; la cría de animales domésticos y huerta de hortalizas y frutas eran complementarias (Pérez, 2008).

En las últimas décadas, la milpa ha disminuido su importancia económica y como medio de sustento familiar; las familias jóvenes tienen actividades de otros sectores laborales como principal fuente de ingreso, sin embargo, adquirieron y poseen saberes productivos. La transmisión de esos saberes ha llegado hasta las nuevas generaciones, pero han sido poco explorados y potencializados.

Ese saber productivo presente en la niñez, aunado a ser un factor del vínculo identitario, es un elemento fundamental y potencial para un proceso de regeneración campesina como alternativa para alimentarse mejor y como semilla en la inclusión de la niñez en el proceso productivo. Es un factor importante, sobre todo, en espacios donde la alimentación de las nuevas generaciones está basada principalmente en los productos que llegan de fuera, donde la alimentación de los niños y niñas tiene pocas frutas y verduras y en su ingesta diaria hay golosinas y productos chatarra.

Actualmente no existen acciones directas con la niñez, ni comunitarias ni gubernamentales, para regular el consumo de productos chatarra. No hay espacios dedicados a la niñez para reflexionar respecto a su alimentación, no se les integra como agentes sociales, ni desde la participación que es un derecho, ni desde la información brindada para que asuman una alimentación sana. 
contribute to the configuration of a more inclusive and diverse environment.

In addition to the contributions of agency and learning, the harvested backyards and the school garden offered a nutritional complement to the families, which can be permanent if the interest in the children is maintained, and if they are given accompaniment and favorable conditions. How food is sown, cared for and harvested is part of the community culture and the children know this because it is part of their experiences with their grandparents and parents. The loss of these experiences will lead to the breakdown of the intergenerational transmission of knowledge.

\section{BACKYARD PRODUCTION AND CHILDREN}

After identifying the practices, knowledge and feelings linked to food, it is worth asking which ones could be strengthened with and from children. Training-productive activities were defined together with the children in order to recognize and strengthen practices and habits that promote healthy eating and are linked to their sociocultural conditions and possibilities.

There are some decisions that children do not freely make, such as what to eat, which is influenced in the first place and directly by their parents. Likewise, their food tastes are influenced by the marketing of the entertainment industry, which also influences adults. Some products were recognized as being harmful to health, yet they are commonly consumed in their family. Food industry companies have control over all of society; in this regard, children
A pesar de que a nivel nacional existen decretos internacionales a favor de los derechos de la niñez, igual que en San Jerónimo, a nivel país existe el reto de abrir esos espacios de participación a los niños, donde puedan opinar y ser escuchados, para construir en colaboración con ellos sus presentes y futuros. En este marco es imprescindible promover las condiciones estructurales, locales y culturales para hacer efectivos esos derechos. La intención de este trabajo no fue victimizar a esa generación, sino mostrar las alternativas desde el protagonismo y reconocerlos como agentes de cambio, que tienen sus propias percepciones del mundo y saberes para aportar en la configuración de un entorno más inclusivo y diverso.

Además de los aportes de agenciamiento y aprendizaje, los traspatios cosechados y el huerto escolar ofrecieron un complemento nutricional a las familias, que puede ser permanente si se mantiene el interés en los niños, si se les da acompañamiento y condiciones favorables. El cómo se siembra, se cuida y se cosecha un alimento, forman parte de la cultura comunitaria y los niños lo saben porque forma parte de sus vivencias con sus abuelos y padres, la pérdida de esas experiencias llevará a la ruptura de la transmisión intergeneracional de saberes.

\section{ELTRASPATIO EN PRODUCCIÓN Y LA NIÑEZ}

Después de identificar las prácticas, conocimientos y sentires vinculados a la alimentación, cabe preguntarse cuáles podían fortalecerse con y desde los niños 
are exposed to the same global forces as adults, forces that frame their eating practices and habits.

Establishing a backyard garden or energizing and extending what already exists were viable options to expand the possibilities of what to eat of these children and what to do based on their agency, with the collaboration of the adults. The gardens were established mainly for configurative and constructive purposes in a process of raising children's awareness of the food practices linked to their land and to the forms of peasant production.

Answering the question "Which of these practices that provide healthy food can be strengthened with and by children?" implied recognizing that in order to strengthen food practices in children, it is not only necessary for them to know how to do it, but also to want to do it and be able to do $i t$. The production in their backyards and the training workshops were viable in all three conditions.

The establishment of backyard production involved collaborative work; a workshop was held to recognize the needs of plants to grow, in which the children gave a complete picture of the cultivation process (Table 2). Their production knowledge and interest in playful activities were used in the establishment of their own "garden." They were always willing to participate in practice activities, they stayed active and kept learning, and they participated and became more interested when learning was collaborative and experiential. y niñas. Se definieron actividades formativo-productivas en conjunto con la niñez para el reconocimiento y fortalecimiento de prácticas y hábitos que promuevan una sana alimentación y estén vinculados a sus condiciones y posibilidades socioculturales.

Hay algunas decisiones que la niñez no toma libremente como el qué comer, la cual es influida en primera instancia y directamente por sus padres, asimismo, sus gustos alimenticios se ven influidos por la mercadotecnia de la industria del entretenimiento, que también influye a los adultos. Se reconoció que algunos productos son dañinos para la salud, sin embargo, en su familia se consumen ordinariamente. Las empresas dedicadas a la industria de la alimentación tienen un control sobre toda la sociedad, al respecto niños y niñas están expuestos a las mismas fuerzas globales que los adultos, fuerzas que enmarcan sus prácticas y hábitos alimenticios.

Instalar un huerto de traspatio o dinamizar y ampliar el que ya se tuviera, fueron opciones viables para ampliar las posibilidades en el qué comer de esa niñez y en el qué hacer desde su agencia, con la colaboración de los adultos. El propósito principal de los huertos fue con fines configurativos y constructivos en un proceso de concientización de la niñez sobre las prácticas de alimentación vinculadas a su tierra y a las formas de producción campesina.

Responder la pregunta ¿Cuáles de esas prácticas que aportan una alimentación sana se pueden fortalecer con y desde niños y niñas? implicó reconocer que para poder fortalecer las prácticas alimentarias 
Table 2. Plant needs

Cuadro 2. Necesidades de las plantas

Type / Tipo
$\begin{aligned} & \text { Physical/Físicas } \quad \text { Water, rain, earth, potting soil, ligh, lluvia, tierra, tierra de ma } \\ & \text { Ague it time and care./Darle tiemp }\end{aligned}$
Attentive/De afecto $\quad$ Source: Author-made.
Fuente: Elaboración propia.
As for being able to do it, this refers not so
much to their individual capacity or abili-
ty, but rather to the conditions that would
impede their realization and involve nego-
tiation between caregivers and children,
both for the decision to establish or not a
garden, the place and the choice of seed.
This ability to do was also assessed on the
basis of external factors such as the envi-
ronment and climate.

Eighteen vegetable gardens were established and managed by the children as the main responsible parties, who appropriated their production spaces, both at school and at their homes; the parents prepared the land and offered the conditions for them to plant the seed, care for the plants and harvest them.

Among the children's perceptions and visions regarding the harvest, what stands out is that it acquires both a use and an exchange value; their fruit and vegetable production is to be eaten and sold inside and outside the community, as part of the strategies of this rurban space.

Only one school garden was set up, in order to serve as a demonstration, ex-
Need / Necesidad

en la niñez no solo es necesario que ellos sepan cómo hacerlo, sino querer hacerlo y poder hacerlo. La producción en sus traspatios y los talleres formativos fueron viables en las tres condiciones.

El establecimiento de producción en traspatio implicó un trabajo colaborativo, se realizó un taller para reconocer las necesidades de las plantas para crecer, niños y niñas dieron un panorama completo (Cuadro 2). Se aprovecharon sus saberes de producción y su interés por las actividades lúdicas en el establecimiento de su propio "huerto". Siempre estuvieron dispuestos a las actividades prácticas, se mantuvieron activos y aprendiendo, participaron y se interesaron más cuando el aprendizaje fue colaborativo y vivencial.

En cuanto al poder hacerlo, se refiere no tanto a su capacidad o habilidad individual, sino a las condiciones que impedirían su realización e implicaban la negociación entre cuidadores e hijos, tanto para la decisión de hacer o no huerto, el lugar y la elección de semilla. Ese poder hacer también se dimensionó desde los factores externos como ambientales y climáticos. 
change and learning space, where children could experiment, discover and have fun, and where they reinforced what they know and became protagonists of a constructive-productive process. The following were some of the achievements:

-Alternatives for healthy eating were explored through collective and individual action and reflection.

-Children's knowledge, participation and agency related to food production were valued.

-The gap between parents' and children's capacity to collaborate in food production was reduced.

-The power over these children in a learning space was diminished, which gave them the opportunity to feel like protagonists and as the ones responsible for a process.

-Knowledge was explored and built from a playful and constructivist perspective.

-Good use was made of spaces that had been idle.

-It was a nutritional source because the harvest came to the school canteen.

-The children were encouraged not to fear making mistakes.

-Differences were recognized and worked with.
Se instalaron 18 huertos con hortalizas y fueron manejados por los niños y niñas como principales responsables, quienes se apropiaron de sus espacios de producción, tanto en la escuela como en sus hogares, los padres prepararon la tierra y ofrecieron las condiciones para que aquéllos plantaran la semilla, la cuidaran y la cosecharan.

Entre las percepciones y visiones de esa niñez con respecto a la cosecha, se destaca que adquiere un valor tanto de uso como de cambio; la producción de sus frutales y hortalizas es para comerse y como mercancía que se vende dentro y fuera de la comunidad, como parte de las estrategias de ese espacio rururbano.

Se instaló solo un huerto escolar, un espacio demostrativo, de intercambio y aprendizaje, donde niños y niñas pudieron experimentar, descubrir y divertirse, donde reforzaron lo que saben y se convirtieron en protagonistas de un proceso constructivo-productivo. Los siguientes fueron algunos logros:

-Se exploraron alternativas para alimentarse saludablemente, mediante la acción y la reflexión colectiva e individual.

-Se valoró el conocimiento, participación y agencia de la niñez en la producción de alimentos.

-Disminución de la brecha entre la capacidad de los padres e hijos en la colaboración de producción de alimentos.

-Se disminuyó el poder sobre esos niños y niñas en un espacio de aprendiza- 
The more leeway the children were given in terms of choosing and deciding how to run their own garden, the more involved they became and the more fluid their opinion became. It is necessary to give them more protagonism spaces that strengthen their agency and their self-confidence, thus allowing them to make mistakes and experiment.

Structural and cultural conditions permeated the entire research work process. Children's participation and agency were mainly influenced by the power that adults have and from which action research could not be derived. Obviously, the power over children was not eliminated, nor was it intended to be yielded instantaneously, but the focus and guiding activities were aimed at reducing it and making their participation more open, with the firm conviction that inclusive relationships in social construction make a more human and diverse reality.

In the perspective of social food change, children's agency is also influenced by the control of the socioeconomic macro-structure, through the media. Permanent and localized work enmeshed in everyday life can have a positive effect on changing habits towards healthier eating, in addition to fostering critical positions regarding everything that comes into their community, their homes and their stomachs.

TV food advertising is playing an important role in tastes and preferences, especially of the new generations. Nevertheless, the culture of peasant production possessed by the grandparents plays a sig- je, que les dio la oportunidad de sentirse protagonistas y responsables de un proceso.

-Se exploró y se construyó conocimiento desde una perspectiva lúdica y constructivista.

-Aprovechamiento de espacios que habían estado ociosos.

-Fue una fuente nutricional, porque la cosecha llegó al comedor escolar.

-Se motivó a los niños y niñas a no temer a equivocarse.

-Se reconocieron diferencias y se trabajó con ellas.

Mientras más apertura en la elección y decisión, se les ofrecía a niños y niñas para dirigir su huerto, su participación se tornaba más protagónica y su opinión más fluida. Es necesario darles más espacios de protagonismo que fortalezcan su agencia y su autoconfianza, dejar que se equivoquen y experimenten.

Las condiciones estructurales y culturales permearon todo el proceso de trabajo investigativo. La participación y agencia de la niñez se vio influida principalmente por el poder que tienen los adultos y del cual no se podría desprender la investigación-acción. Evidentemente, el poder sobre los niños y niñas no se eliminó, hecho que tampoco se buscaba que se diera instantáneamente, sin embargo, el enfoque y las actividades guía se encaminaron a disminuirlo y dar más apertura a su 
nificant role in the knowledge and internalized feelings of children and objectively can provide to a greater extent that nutritional supplement that they need to have a more varied diet; in addition, it is an identity link with their predecessors, their physical environment and their community.

Governmental, structural and cultural actions are needed that simultaneously reinforce and promote social actions by and with children. However, government agencies do not have the information or institutional capacity to deal with the food problems of the San Jerónimo community.

In this work, the openness of adults to collaborate in the agency of their children is commended. This work gave children the opportunity to decide and participate, representing one of the central points of action to attack the lack of information, with the clarity that these problems are structural and systemic and cannot be solved from a single front.

It was possible to understand the food situation of a group of children, with which there are now elements that would help improve it by initiating a long-term research work process with children as social agents and with the physical-sociocultural space as the main starting points. Knowing children as social agentsallowedustounderstandandapproach other realities that are not possible from an adultcentrism paradigm.

\section{CONCLUSIONS}

In principle, the idea that only adults can decide and act with respect to healthy eat- participación, con la firme convicción de que las relaciones incluyentes en la construcción social hacen una realidad más humana y diversa.

En perspectiva de cambio social alimenticio, la agencia de la niñez también se ve influida por el control de la macroestructura socioeconómica, a través de los medios de comunicación. Un trabajo permanente y localizado desde la cotidianeidad puede tener un efecto positivo en el cambio de hábitos hacia una alimentación más saludable y con posiciones críticas con respecto a todo lo que llega a su comunidad, a sus hogares y sus estómagos.

La propaganda televisiva de alimentos que se ofertan desde las industrias está jugando un papel importante en los gustos y preferencias, sobre todo, de las nuevas generaciones. No obstante, la cultura de producción campesina que poseen los abuelos juega un papel significativo en el conocimiento y sentir interiorizado de la niñez y objetivamente puede aportar en mayor medida ese complemento nutricional que necesitan para tener una alimentación más variada, además, es un vínculo identitario con sus antecesores, su entorno físico y su comunidad.

Son necesarias acciones gubernamentales, estructurales y culturales que simultáneamente refuercen y promuevan las acciones sociales de y con niños y niñas. Sin embargo, las agencias gubernamentales no tienen la información, ni capacidad institucional necesarias para hacer frente a los problemas alimentarios de la comunidad de San Jerónimo, pese a la situación, 
ing for children remains to be overcome. Then, based on a new ideology, alternatives, ways and situations must be sought so that children are included in these decisions and changes. In San Jerónimo, the prevailing forms of community organization, such as community work projects, assemblies and the guard system, allow its inhabitants to see the importance of participation, a community characteristic that represents advantages for the inclusion of children in community actions.

In this work, a commitment was made to let error be a natural part of the activities in order to learn to do and to diminish control; this helped the children feel more motivated and open to collaboration and decision-making. The decrease in power relations made agency possible, which is why it is suggested that future works hypothesize an inverse relationship between an increase in child agency and a decrease in the adult-centric domination they are subjected to.

The capacity of children between six and eight years of age in San Jerónimo has been underestimated. Children's agency is necessary in food issues because they have been vulnerable and affected, but they have not been offered options so that they can act to improve their diet. Recognizing their agency is essential for them to be part of a process of raising awareness of the importance not only of knowing how to produce food, but also of doing it to reduce dependence on products that come from outside in spaces where there are conditions, knowledge and possibilities to produce there. If the physical conditions, knowledge and attitude exist in children for them to contribute to food se- hay cambios que son posibles desde la propia comunidad.

En este trabajo, se rescata la apertura de los adultos a colaborar en el agenciamiento de sus hijos. Este trabajo dio la posibilidad a la niñez de decidir y participar, representó uno de los ejes de acción para atacar la falta de información, con la claridad de que esos problemas son estructurales y sistémicos y no se solucionan desde un solo frente.

Se logró comprender la situación alimentaria de un grupo de niños y niñas, con lo cual se tienen ahora elementos que ayudarían a mejorarla iniciando un proceso de trabajo investigativo a largo plazo con la niñez como agente social y con el espacio físico-sociocultural como principales puntos de partida. Conocer a la niñez como agente social, permitió comprender y acercarse a otras realidades que desde un adultocentrismo no es posible.

\section{CONCLUSIONES}

En principio, falta superar la idea de que solo los adultos pueden decidir y actuar con respecto a la alimentación sana de la niñez. Después, a partir de una nueva ideología buscar alternativas, vías y situaciones para que la niñez se incluya en esas decisiones y cambios. En San Jerónimo, las formas de organización comunitarias prevalecientes, como las faenas, asambleas comunitarias y sistema de guardias permiten a sus habitantes vislumbrar la importancia de la participación, una característica comunitaria que representa ventajas para la inclusión de la niñez en acciones comunitarias. 
curity, it is necessary to provide them with the required social conditions and accompaniment to promote their self-confidence and freedom so that they experiment and discover that they can achieve it.

The results are a precedent to suggest that the peasant culture that persists in the grandparents can be renewed through the grandchildren and that if social spaces are opened up to them, children can collaborate in the process of food sovereignty needed by peoples and communities. Similar results elsewhere may be possible, particularly where community relationships exist and where the transmission of the grandparents' agricultural and food knowledge is still possible.

An intergenerational strategy could prevent diseases resulting from poor nutrition and build a food culture more linked to physical space and identity. The bond with the land is more enduring if everyone is involved, and if the ideology that nature provides sustenance if it is consciously cared for and used is reinforced in childhood.

For this, there is a lack of differentiated actions and studies from academic research and public policy that allow recognizing and including children, from a formative-productive approach, in the valuation of food as a relevant aspect in their lives, both for their health and for the strengthening of their community identity, through the recognition of the natural and sociocultural wealth that they collectively possess and which is the basis of the productive phase of a healthy and culturally relevant diet.

End of English vesion
En este trabajo se apostó por dejar que el error fuera parte natural de las actividades para aprender a hacer y disminuir el control; esto ayudó a que los niños se sintieran más motivados y abiertos a la colaboración y a tomar decisiones. La disminución de relaciones de poder posibilitó la agencia, por lo cual, se sugiere en futuros trabajos plantear como hipótesis, una relación inversa entre incremento de agencia infantil y disminución de la dominación adultocéntrica de que son objeto.

Se ha subvalorado la capacidad de la niñez entre seis y ocho años en San Jerónimo. La agencia de niños y niñas es necesaria en temas alimenticios porque han sido vulnerados y afectados, pero no se les han ofrecido opciones para que puedan actuar en el mejoramiento de su alimentación. Reconocer su agencia es imprescindible para que formen parte de un proceso de concientización de la importancia, no solo de saber cómo producir alimentos, sino de hacerlo para disminuir la dependencia a productos que provienen del exterior en espacios donde hay condiciones, conocimientos y posibilidades para producir ahí. Sí existen las condiciones físicas, los conocimientos y la actitud en la niñez para que contribuya en la seguridad alimentaria, falta darle las condiciones sociales y el acompañamiento, fomentar su autoconfianza y la libertad para que experimenten y descubran que pueden lograrlo.

Los resultados son un precedente para sugerir que la cultura campesina que persiste en los abuelos puede renovarse mediante los nietos y si se les abren los espacios sociales, la niñez puede colaborar en 


\section{REFERENCES / REFERENCIAS}

Aguilar Piña, P. (2001). Por un marco teórico conceptual para los estudios de antropología de la alimentación. Anales de antropología, 35, 11-29.

Aguilar Piña, P. (2014). Cultura y alimentación. Aspectos fundamentales para una visión comprensiva de la alimentación humana. Anales de antropología, 48 (1), 11-31.

Ayora Díaz, S. (2017). Introducción a la sección temática "Perspectivas críticas en la antropología de la comida y la alimentación”. Anales de Antropología 51, 94-95.

Bertran Vilà, M. (2010). Acercamiento antropológico de la alimentación y salud en México. Physis: Revista de Saúde Coletiva, 20(2), 387-411.

Blanco-García, I., \& Florence, T. R. (2016). Frentes culturales: una aportación teórica y metodológica al estudio de la alimentación. Razón y Palabra, 20(94), 132145.

Bustelo Graffigna, E. (2012). Notas sobre infancia y teoría: un enfoque latinoamericano. Salud colectiva, 8(3), 287-298.

Cardoso, M. M., \& Fritschy, B. A. (2012). Revisión de la definición del espacio rururbano y sus criterios de delimitación. Contribuciones científicas GAEA, 24, 27-39.

Consejo Nacional de Evaluación de la Política de Desarrollo Rural (CONEVAL). (2014). Pobreza en México, resultados de pobreza en México 2014 a nivel nacional y por entidades federativas.

Dietz G., \& Álvarez Veinguer A. (2014). Reflexividad, interpretación y colaboración en etnografía: un ejemplo desde la antropología de la educación. En Cristina Oehmichen Bazán (editora) el proceso de soberanía alimentaria que necesitan los pueblos y comunidades. Resultados similares en otros lugares puede ser posible, particularmente cuando existen relaciones comunitarias y donde la transmisión de los conocimientos agrícolas y alimentarios de los abuelos son todavía posibles.

Con una estrategia intergeneracional se podrían prevenir enfermedades derivadas de la mala alimentación y construir una cultura alimentaria más ligada al espacio físico e identitario. El vínculo con la tierra es más perdurable si se involucra a todos, si se refuerza la ideología en la niñez de que la naturaleza provee de sustento si se le cuidada y aprovecha conscientemente.

Para esto, faltan acciones y estudios diferenciados desde la investigación académica y la política pública que permitan reconocer e incluir a la niñez, desde un enfoque formativo-productivo, en la valoración de la alimentación como un aspecto relevante en su vida, tanto para su salud como para el fortalecimiento de su identidad comunitaria, por medio del reconocimiento de la riqueza natural y sociocultural que poseen colectivamente y que es base de la fase productiva de una alimentación sana y con pertinencia cultural.

Fin de la verción en español

La etnografía y el trabajo de campo en las ciencias sociales (pp.55-98.). México: Universidad Nacional Autónoma de México.

Fondo de las Naciones Unidas para la Infancia (UNICEF). (2016). Pobreza y equidad. Re- 
cuperado de http://www.unicef.org/mexico/spanish/17046.htm

Gaitán Muñoz, L. (2006). La nueva sociología de la infancia. Aportaciones de una mirada distinta. Política y Sociedad, 43 (1), 9-26.

Glockner Fagetti, V. (2007). Infancia y representación. Hacia una participación activa de los niños en las investigaciones sociales. Tramas. subjetividad y procesos sociales, 28 (1), 67-83.

Instituto Mexicano del Seguro Social. (2014). Obesidad infantil: Un problema de salud. Revista médica del Instituto Mexicano de Seguridad Social, 52.

Mansilla A, M. E. (2000). "Etapas del Desarrollo Humano”. Revista de Investigación en Psicología, 3 (2), 105-116.

Nájera Castellanos, A. \& Álvarez Gordillo, G. (2010). Del posol a la Coca Cola: cambios en las prácticas alimentarias en dos comunidades tojolabales. LiminaR, 8(1), 173-190.

Ochoa Rivera, T. (2013). Alimentación y diferenciación social: el caso de una comunidad en México. Revista Internacional de Ciencias Sociales, 2(1).

Papalia, E., Wendkos, O. \& Duskin, F. (2004). Desarrollo Humano. México: McGraw Hill.

Pérez Lizaur, M. (2008). Población y sociedad: cuatro comunidades del Acolhuacan. México D. F.: Universidad Iberoamericana.

Pia Haudrup, C. (2004). Children's Participation in ethnographic research: Issues of Power and Representation. Children \& Society, 18, 165-176.

Quecha Reyna, C. (2014). Etnografía con niños. En Cirstina Oehmichen Bazán (editora) La etnografía y el trabajo de campo en las cien- cias sociales (pp. 215-240). México: Universidad Nacional Autónoma de México.

Quizán Plata, T., Anaya Barragán C., Esparza Romero J., Orozco García M., Espinoza López M. \& Bolaños Villar A. (2013). Efectividad del programa Promoción de alimentación saludable en estudiantes de escuelas públicas del estado de Sonora. Estudios Sociales 42, 177-203.

Ramírez Miranda, C. 2017. Contribuciones teóricas al debate sobre el campo. Revista ALASRU 11.

Reygadas, L. (2014). Todos somos etnógrafos. Igualdad y poder en la construcción del conocimiento antropológico. En Cirstina Oehmichen Bazán (editora) La etnografía y el trabajo de campo en las ciencias sociales (pp. 91-118). México: Universidad Nacional Autónoma de México.

Rodríguez Pascual, I. (2007). Para una sociología de la infancia: aspectos teóricos y metodológicos. Madrid: Centro de investigaciones sociológicas.

Pelcastre, Riquer, de León, Reyes, Gutiérrez, \& Bronfman, (2006), ¿Qué se hace para no morir de hambre? Dinámicas domésticas y alimentación en la niñez en un área rural de extrema pobreza de México. Salud Pública, México. 2006; 48:490-497.

Sobrino, J. (2003). Rururbanización y localización de las actividades económicas en la región centro del país, 1980-1998. Sociológica, 18 (51), 99-117.

Yopo Díaz, M. (2016). El tiempo de las mujeres en Chile: repensar la agencia. Revista de Estudios Sociales, (57), 100-109.

Zanabria Salcedo M., Fragoso Astorga B., \& Martínez Esparza A. (2007). Experiencias de participación infantil en Tlaxcala y Ciudad de México. Tramas. subjetividad y procesos sociales, 28, 121-140. 